III

\title{
OTWARTE KODY ŹRÓDŁOWE I MODA
}

\begin{abstract}
Alicja Raciniewska, Otwarte kody źródłowe i moda [Open source and fashion], edited by M. Baranowski, „Człowiek i Społeczeństwo”, vol. XL, Poznań 2015, pp. 157-173, Adam Mickiewicz University Press. ISBN 978-83-232-2964-3, ISSN 0239-3271.

The impact of the Internet and digital technologies on the contemporary fashion system is undeniable and evident in almost every aspect of its operation - in the techniques of design, material production, sales and distribution, methods of communication, consumption and, finally, the fashion education. There is no place to discuss all these areas in this article, so therefore, I will focus on the issue relatively poorly discussed in our country, which is the application of the open source philosophy in fashion. In the first part of this article the most important assumptions of the open source movement is presented. The second discusses the most important actors and practices of open source in fashion. The final part of the article is devoted to the evaluation of the analyzed phenomenon.

Alicja Raciniewska, Uniwersytet im. Adama Mickiewicza w Poznaniu, Instytut Socjologii, ul. Szamarzewskiego 89c, 60-569 Poznań, Poland, e-mail: alicjar@amu.edu.pl
\end{abstract}

\section{Otwarte kody źródłowe}

Komunikacja, partycypacja społeczna, dostęp do informacji, narzędzia i ich używanie w celu dalszej demokratyzacji życia są najważniejszymi zdobyczami rozwoju technologii cyfrowych i Internetu. W sferze mody doprowadziło to nie tylko do kolejnych ataków na powierzchowne aspekty kapitalizmu i systemu mody, ale dostarczyło także informacji i narzędzi działania dostępnych użytkownikom za darmo, a wraz z rozwojem Sieci 2.0 dało obietnicę zmiany biernych konsumentów mody w jej aktywnych współ- 
twórców, zdolnych prowadzić własne eksploracje Sieci i rozwijać kapitał społeczny za pomocą środków technicznych ${ }^{1}$.

Filozofia otwartych kodów źródłowych, otwartej kultury i ekonomii jest częścią kultury Internetu od jej narodzin i powstania BBS (Bulletin Board Systems) i BASIC, kodów źródłowych dystrybuowanych za pośrednictwem kanałów sieciowych w latach 80. XX wieku. Internet umożliwił dalsze dzielenie się kodami poprzez systemy UUSP, Usenet i Linux, choć korzystały z nich głównie społeczności skupione wokół środowisk inżynierskich z AT\&T Labs, Duke University, IBM, Stanford czy MIT. Papierowego prototypu dzisiejszego Internetu i ruchu otwartych źródeł poszukiwać można jednak już w wydawanym od 1968 r. pod redakcją amerykańskiego biologa Stewarda Branda, kontrkulturowym magazynie „The Whole Earth Catalog”2. Zawierający m.in. instrukcje samodzielnego tworzenia rzeczy, akcentował on wiele wartości charakterystycznych dla zwolenników otwartych kodów źródłowych: wolność, transparencję, współpracę, DIY, dzielenie się, upodmiotowienie.

Ruch Open Source ma źródła w filozofii Unixu i zapoczątkowany został przez środowisko osób związanych z tym systemem. Jego prekursorem był Richard Stallman, wieloletni haker w Laboratorium Sztucznej Inteligencji MIT, twórca nieformalnego projektu GNU i Free Software Fundation (FSF) ${ }^{3}$, koncepcji „,copyletf”“4 oraz działacz ruchu na rzecz wolnego oprogramowania, rozumianego jako projekt polityczny i moralny. Podejście Stallmana różni się od podejścia prezentowanego przez ruch otwartych źródeł, którego ważną postacią jest Eric Raymond, programista uniksowy, haker, twórca wielu opracowań teoretycznych, m.in. manifestu The Cathedral and the Bazaar $^{5}$, w którym opisał dwa sposoby rozwoju oprogramowania: model

${ }^{1}$ D. Beer, R. Burrows, Sociology and, of and in Web 2.0: Some Initial Considerations, 2007, http://goo.gl/btDwNR [13.06.2014].

2 „The Whole Earth Catalog”, http://goo.gl/6pizmW [10.06.2014].

${ }^{3}$ Głównym celem GNU Project było opracowanie darmowej wersji systemu Unix, jako reakcji na jego komercjalizację przez AT\&T i wprowadzaniu ograniczeń w dostępie do kodu źródłowego. Fundacja Wolnego Oprogramowania (FSF) była zapleczem organizacyjnym, finansowym i promocyjnym przedsięwzięcia, mając ogromny wpływ na powstanie ruchu na rzecz wolnej kultury.

${ }^{4}$ „Copyleft” jest systemem licencji praw autorskich opracowanym w 1984 r., pozwalającym na modyfikację i dalszą redystrybucję pracy na takich samych warunkach. Idea licencji polega na wykorzystaniu systemu praw autorskich do osiągnięcia celów odwrotnych niż „copyright”, czyli rozszerzania wolności zamiast jej ograniczania.

${ }^{5}$ E. Raymond, The Cathedral and The Bazaar. Musings on Linux and Open Source by an Accidental Revolutionary, Cambridge, Mass. 2001. 
„katedry” (gdzie kod źródłowy zna i tworzy jedynie wąska grupa programistów) i model „bazaru” (gdzie kod tworzony jest w Internecie na oczach wszystkich i przy współudziale zainteresowanych). Zwolennicy otwartych kodów źródłowych działają bardziej pragmatycznie i demokratycznie pod egidą Open Source Initiative (OSI) założonego w 1998 r. w celu promocji alternatywnego modelu biznesowego.

Istotą produktów i praktyk open source jest to, że umożliwiają analizę, samodzielną kompilację oraz wprowadzanie modyfikacji do kodu każdemu zainteresowanemu tym podmiotowi. Ruch wolnych źródeł opowiada się za wolnością rozumianą jako przepływ idei i myśli ludzkiej, których nośnikiem jest m.in. oprogramowanie komputerowe. Nie oznacza to jednak, że produkty te muszą być udostępnianie za darmo.

Pierwotnie idee open source dotyczyły wyłącznie oprogramowania komputerowego i kultury hakerskiej, z czasem zyskały zastosowanie także w innych dziedzinach życia społecznego. Ich popularyzacja zbiegła się z rozwojem dot-comów pod koniec XX wieku i dziś przeżywa rozkwit po kryzysie ekonomicznym 2008 r. Skojarzony z takimi określeniami, jak: społeczny, dzielenie się, współtworzenie, transparencja, DIY, podmiotowość, traktowany jest jako model zapobiegający monopolizacji rynku przez dużych graczy i nieuzasadnionemu wzrostowi cen oraz pozwalający znacznie redukować koszty rozpoczęcia kreatywnej działalności gospodarczej. Z tego względu idea otwartych źródeł jest szczególnie bliska przedstawicielom przemysłów kreatywnych.

\section{Hacking Couture i haktywizm modowy}

Jednym z najbardziej wyraźnych przykładów zastosowania filozofii otwartych kodów źródłowych w modzie są praktyki haktywizmu modowego, którego najważniejszymi reprezentantami są Giana Pilar González i Otto von Busch. Posiadając wykształcenie w dziedzinie architektury i programowania komputerowego, González od 2006 r. prowadzi projekt hackingcouture.com, poświęcony kodom i strukturom marek, technologii i systemów kultury. Stosując metody projektowania partycypacyjnego ${ }^{6}$ oraz prognozowania trendów w modzie, bada ona kody mody w celu otwarcia ich i tworzenia nowych rodzajów produktów, form zaangażowania i doświadczeń użytkow-

${ }^{6}$ L. Sanders, B. Westerlund, Experiencing, Exploring and Experimenting in and with Co-Design Spaces, 2011, http://goo.gl/tXmVuY [30.05.2014]; L. Sanders, P. Stappers, Co-creation and the new landscapes of design, „CoDesign” 4(1)/2008, ss. 5-18. 
ników. Z kolei Otto von Busch praktykuje i propaguje filozofię haktywizmu w licznych publikacjach i wykładach oraz serii projektów dokumentowanych na jego stronie internetowej selfpassage.org.

„Haktywizm” jest pojęciem wprowadzonym przez von Buscha i stanowi połączenie praktyki hakowania z politycznym aktywizmem, bowiem hakowanie jest procesem jednocześnie estetycznym i politycznym ${ }^{7}$. W odniesieniu do omawianej branży będzie on oznaczać praktyki wymagające dostępu do technologii projektowania w modzie oraz decentralizacji kontroli, skutkujące upodmiotowieniem jej użytkowników. Jego celem jest wyzwolenie spod dyktatu wielkich firm modowych, redukcja konsumpcjonizmu, wzmocnienie lokalnych struktur i rzemieślnictwa, poszerzanie modowych kompetencji oraz pełne oddanie mody w ręce jej użytkowników.

Termin „hakowanie” odnosi się do klasycznej definicji powstałej w środowisku pierwszych programistów z MIT w latach 60. XX wieku i rozumiany jest jako działalność społeczności hakerów, czyli grupy programistów dzielących się kodem źródłowym, wymieniających osiągnięciami i uczących się wzajemnie „sztuczek” lub lepszych sposobów programowania. Pojęcie to ma konstruktywny, a nie negatywny wydźwięk, jaki nadają mu media masowe, używające go do określania osób i działań łamiących zabezpieczenia systemów komputerowych. Hakerzy tego rodzaju działania nazywają z kolei „crackingiem” i źle widzą utożsamianie ich z „crackerami”, gdyż - jak ujął to Eric Raymond - „hakerzy budują rzeczy, crackerzy je niszczą”. Dla haktywistów hakowanie oznacza: 1) umiejętność otworzenia systemu i uczenie się opanowywania jego obwodów, zabezpieczeń i struktur; 2) taktykę zmiany systemu poprzez podłączanie się do niego i przebudowywanie go, przekierowywanie jego przepływów w bardziej pożądanym kierunku; 3) dzielenie się za darmo metodami, technikami i narzędziami z innymi uczestnikami systemu, tak że każdy może zmienić lub rozwinąć nową aplikację9.

Haktywiści postrzegają modę jako pewien zbiór kodów, który można otworzyć i przekształcać dowolnie, jednak „nie z nienawiści, ale z miłości do systemu"10, tj. nie w celu burzenia czy wyłączania całej maszynerii mody, ale w celu jej ulepszania i zabawy z nią. Punktem wyjścia ich działalności jest krytyka niektórych paradygmatów nowoczesnego systemu mody oraz

\footnotetext{
${ }^{7}$ McKenzie Wark, A Hackers Manifesto, Cambridge 2004.

${ }^{8}$ E. Raymond, How To Become a Hacker, 2001, http://goo.gl/1PLWiP [15.06.2014].

${ }^{9}$ O. von Busch, Engaged Design and the Practice of Fashion Hacking: Examples of Giana Gonzalez and Dale Sko, „Fashion Practice” 1(2)/2009, s. 164.

${ }^{10}$ O. von Busch, Fashion-able. Hacktivism and engaged fashion design, Göteborg 2008, ss. 41-42.
} 
krytyka dotychczasowej krytyki i strategii aktywistycznych względem systemu mody.

Haktywiści są przede wszystkim krytyczni wobec demokratyzacji mody. Dostrzegają, że coraz więcej osób włącza się w orbitę planety moda, co nie oznacza ich zdaniem automatycznie pełnej demokratyzacji systemu mody. Podkreślają, że nowoczesny system mody wciąż bardziej przypomina katedrę niż bazar - jest strukturą hierarchiczną, stosunkowo zamkniętą, cechującą się elitarnością, centralizacją władzy i uprzywilejowaniem pewnych pozycji względem innych. Według nich nie można mówić o pełnej demokratyzacji mody, gdyż istnieje w niej nadal nierówna relacja między twórcami mody (aktywni, którym przypisana jest kreatywność i kontrola nad przekazem i kształtem oferty) a jej odbiorcami (bierni, wykluczeni z procesu produkcji materialnej i symbolicznej mody, a działania ich są ograniczone do wyboru z dostarczonej oferty produktów) ${ }^{11}$. W modzie nowoczesnej, podobnie jak w innych systemach katedralnych, kod źródłowy jest udostępniany wraz z każdą nową wersją programu, ale jego opracowaniem zajmuje się jedynie wąska grupa programistów. Tymczasem kreacja nie jest tylko właściwością wybrańców, a udział w modzie nie sprowadza się jedynie do konsumowania ${ }^{12}$.

Przedmiotem szczególnej krytyki jest jeden z wzorców nowoczesnego systemu mody - figura projektanta-gwiazdy, mit geniuszu i demiurgicznych cech właściwych jedynie wybitnym jednostkom. Dla haktywistów kreacja jest procesem organicznym i kolektywnym, moda nie rozwija się wyłącznie dzięki wybitnym geniuszom, ale dzięki działalności wszystkich jednostek włączonych w jej orbitę; ma wielu twórców, tak materialnych, jak i symbolicznych. W związku z tym system mody powinien zostać przepracowany strukturalnie, by jak najwięcej jednostek mogło w nim uczestniczyć inaczej niż jedynie poprzez konsumpcję jak największej liczby dóbr przygotowanych przez innych.

Przedstawiciele omawianego ruchu krytycznie odnoszą się również do dotychczasowej krytyki systemu mody prezentowanej przez różnego rodzaju aktywistów i przedstawicieli kontrkultury. Szczególnie dystansują się wobec takich praktyk, jak: opór, bojkot, sabotaż, tworzenie antymód czy strategie subwersywne, polegające na przesuwaniu znaczeń, bazującym na manipulacji i cynizmie. Ich zdaniem żadna z tych strategii nie jest skuteczna, gdyż

${ }^{11}$ Ibidem, ss. 46, 108-110.

${ }^{12}$ S. Scaturro, Open Source Fashion: For the Masses, by the Masses, http://goo.gl/ LqKFeI [15.05.2014]. 
zamiast przynieść pożądane przekształcenia systemu, stanowi część wojny podjazdowej prowadzącej ostatecznie do jego umocnienia ${ }^{13}$.

Haktywizm modowy jest w zamyśle jego przedstawicieli próbą przezwyciężenia tych krytyk poprzez program pozytywny, obejmujący idee (czasem też technologie) programów komputerowych i filozofię otwartych kodów źródłowych, by zwiększać podmiotowość użytkowników systemu mody. Postulują oni ideę zaangażowanego designu i odmienny od klasycznego sposób rozumienia roli projektanta w modzie. Celem zaangażowanego designu w modzie jest budowanie wspólnoty zręcznych rzemieślników i rzemieślniczek przy użyciu potencjału mody i przekształcania jej kodów, by stała się bardziej dostępna ${ }^{14}$, a rolą projektanta jest bycie częścią wspólnoty, w której pełni on rolę nauczyciela, koordynatora działań, pedagoga i pomocnika. Najważniejszym jego zadaniem jest pomóc innym doświadczyć magii mody, jej zdolności do transformacji, wzmocnienia i upodmiotowienia. Zwłaszcza Otto von Busch postuluje uczynienie z mody dobra powszechnego ${ }^{15}$.

Podstawowym sposobem działania haktywistów w modzie są warsztaty, podczas których projektanci występują w roli nauczycieli, koordynatorów, współtwórców, pomocników i negocjatorów. Przykładowo warsztaty prowadzone przez Gianę González w galeriach i na uniwersytetach dotyczą przeprogramowania kodów marek haute couture. Uczestnicy spotkania przy pomocy projektantki rozpoznają świat uznanej marki, np. Chanel (poznają jej historię, dzieje jej założycieli, produkty, stosowane materiały, tkaniny, wzory, kolorystykę) i wspólnie tworzą mapę jej kodów. Następnie przygotowują program jej przekodowania i ostatecznie tworzą własne produkty, bazując na dostępnych środkach i założeniach (DNA) analizowanej marki. Narzędzia dekodowania umożliwiają poznanie marki i uczą umiejętności skutecznego wykorzystywania jej rdzenia we własnym projekcie. Jak twierdzi González:

Poprzez wspólny język projektowania chcę dać sobie i innym możliwość podłączenia do czegoś zabawnego i wyzwalającego jak moda ${ }^{16}$.

Co jednak najistotniejsze, idee i techniki cyfrowe łączone są z metodami pracy i narzędziami rzemieślniczymi. Własnoręczne krojenie, szycie, przerabianie odzieży i akcesoriów podczas wspólnych spotkań stają się politycznymi mikrodziałaniami upodmiotowienia, budowania własnych umiejętności i wiedzy na temat działania mody, angażowania się w system

\footnotetext{
${ }^{13}$ O. von Busch, Hacking Design, http://goo.gl/FQXFao [29.06.2014].

${ }^{14}$ O. von Busch, Engaged Design..., s. 183.

${ }^{15}$ O. von Busch, Fashion-able..., ss. 111-125.

${ }^{16}$ S. Scaturro, Open Source Fashion...
} 
współprodukcji ubrań i tym samym przekształcania struktur władzy w modzie na materialnym, duchowym i symbolicznym poziomie.

Inną praktyką haktywistów jest tworzenie serii otwartych bibliotek i modowych „książek kucharskich”, w których projektanci udostępniają za darmo swoje kody, dzielą się wzorami, wykrojami oraz swoją wiedzą. Przykładem mogą być projekty Reform i Recyklopedia - tworzona przez Otta von Buscha seria skryptów, instrukcji „krok po kroku” i gotowych przepisów (instructables), jak przetwarzać stare ubrania. Działa ona na zasadzie źródeł - kolekcji metod, a nie gotowych produktów - otwartych dla każdego, kto chciałby z nich skorzystać ${ }^{17}$.

Inną praktyką jest współpraca haktywistów ze sobą oraz z innymi projektantami i firmami z tradycyjnego systemu mody w celu tworzenia bardziej otwartych projektów modowych. Na przykład jesienią 2007 r. w Turcji miało miejsce wydarzenie Haute Couture Hackers Heretics, w ramach którego kilku projektantów przekształcało na bazie przyjętej filozofii wybrane elementy ostatniej kolekcji tureckiej marki luksusowej Vakko, czyniąc z nich coś nowego lub dodając nowe wartości. Każdy z projektantów miał miesiąc na przekształcenie swojego produktu, przygotowanie dokumentacji jego wykonania i przekazanie go właścicielowi marki, który miał na jej podstawie wykonać 10 sztuk każdego zreformowanego produktu, przygotować ich kampanię reklamową i wystawić do sprzedaży. Prototypy i instrukcje wykonania miały zostać wystawione w tureckiej Garanti Gallery. Mimo że ostatecznie projekt nie został zrealizowany ze względu na wycofanie się z niego tureckiej marki, dokumentacja procesu hakowania i lekcje wyniesione $\mathrm{z}$ tego doświadczenia zostały opisane przez von Buscha ${ }^{18}$.

\section{Openwear i ekonomia współdzielona}

Inną realizacją idei otwartych kodów źródłowych w modzie jest finansowany przez Komisję Europejską projekt openwear.com, rozpoczęty jesienią 2009 r., z inicjatywy słoweńskiej agencji komunikacji społecznej Poper, londyńskiej firmy Ethical Economy oraz trzech europejskich instytucji akademickich: Uniwersytetu Mediolańskiego, Uniwersytetu Lublańskiego i Copenhagen Business School.

${ }^{17}$ O. von Busch, Self_passage>. Collected methods, http://goo.gl/pSzDPZ [15.05. 2014].

${ }^{18}$ O. von Busch, Fashion-able..., ss. 217-230. 
Projekt jest eksperymentalną platformą i społecznością internetową, gdzie „twórcy, producenci mody, niewielcy przedsiębiorcy lokalni, instytucje edukacyjne tworzą sieć w celu uczestnictwa w produkcji nowej wizji mody opartej na mikrospołecznościach i zrównoważonym rozwoju”19. Openwear umożliwia otwarcie własnego showboxu (publiczna przestrzeń prezentowania profilu i aktywności użytkownika), poszukiwanie osób chętnych do współpracy (jako student, badacz, niezależny projektant, przedsiębiorca społeczny), korzystanie i współtworzenie narzędzi wypracowanych i udostępnionych online przez wspólnotę, rozwijające mikrostrategie tworzenia mody, pracy nad wspólnymi zamówieniami, by uzyskać lepsze ceny, rozwiązywania problemów i odkrywania nowych możliwości edukacyjnych. Platforma proponuje też alternatywne podejście do mody poprzez serię „Collaborative Collections”, które są udostępnione do darmowego ściągnięcia i indywidualizacji oraz do produkcji i sprzedaży ubrań i akcesoriów. Na przykład wiosną 2010 r. ośmiu projektantów różnych narodowości wzięło udział w warsztatach, których celem było stworzenie kolekcji Forward to basic. Każdy członek społeczności ma dostęp do kodów źródłowych poszczególnych ubrań (informacji na temat metod i technik ich tworzenia, np. wykroju) i może na ich bazie wyprodukować własne, dowolnie je przekształcić, opatrzyć logo własnego projektu i sprzedać poza siecią. Na stronie projektu publikowany jest również blog na temat społecznych zagadnień związanych z ideą otwartych kodów źródłowych, zrównoważonego rozwoju, filozofią DIY, We-Think ${ }^{20}$ oraz ekonomią etyczną ${ }^{21}$ i ekonomią sieci/ współdzieloną/społeczną/deskali ${ }^{22}$.

Celem omawianego projektu jest przeformułowanie dotychczasowej kultury korporacyjnej, konsumeryzmu i tradycyjnych sposobów produkcji w modzie, aby stworzyć nowy model ekonomiczny, oparty na współdziałaniu na rzecz osiągania wspólnych celów, dzielenia się wiedzą i umiejętnościami w celu produkcji kultury i bogactwa ${ }^{23}$.

${ }^{19}$ http://goo.gl/2C3Uzv [2.06.2014].

${ }^{20}$ Ch. Leadbeater, We Think. Mass innovation not mass production, London 2009.

${ }^{21}$ A. Arvidsson, The ethical economy of customer coproduction, „Journal of Macromarketing” 28(4)/2008, ss. 326-338.

${ }^{22}$ M. Bauwens, The Political Economy of Peer Production, 2006, http://goo.gl/lxjkLK [20.05.2014]; Y. Benkler, The wealth of networks: How social production transforms markets and freedom, New Haven 2006; N. Hatalska, Trend Book 2014, 2014, s. 72, http:// goo.gl/UNcNa2 [27.05.2014].

${ }^{23}$ B. Niessen i in., OpenWear. Sustainability, openness and P2P production in the world of fashion, 2010, s. 7, http://tinyurl.com/kyxppvs [29.06.2014]. 
Openwear działa na zasadzie kolaboratorium opartego na założeniach teorii ekonomii peer-to-peer (P2P), która jest formą produkcji dóbr, usług i zawartości, powiązaną z redukcją pojęcia własności dzieła, wzrostem znaczenia dostępu, zmiany tradycyjnej koncepcji kreatywności zarezerwowanej dla profesjonalistów na rzecz innowacyjności kolektywnej, otwartej. O modelu P2P można mówić, gdy mamy do czynienia z systemem łączącym społeczności wolontariuszy w produkcji dóbr i wartości uznawanych za wspólne, a zatem takich, które mogą być używane, przekazywane i dowolnie przekształcane przez innych użytkowników ${ }^{24}$. W takim systemie produkcja gospodarcza oparta jest na mechanizmie wkładu i prowadzi do akumulacji zasobów wiedzy dostępnych powszechnie do twórczego wykorzystania, nie zaś do akumulacji kapitału ${ }^{25}$. Co jednak najważniejsze, w modelu P2P każdy członek sieci jest beneficjentem wspólnych wysiłków, podczas gdy w systemie kolektywnej produkcji zwanej crowdsourcingiem ${ }^{26}$ pracę wielu osób kapitalizuje niewielka liczba jej końcowych odbiorców ${ }^{27}$. W modelu crowdsourcingu organizacja (firma, instytucja publiczna, organizacja non-profit) przeprowadza outsourcing zadań tradycyjnie realizowanych przez swoich pracowników do niezidentyfikowanej, zwykle bardzo szerokiej grupy ludzi w formie open call. Choć crowdsourcing przedstawiany jest jako „siła tłumu” i przykład tego, jak wkład wielu amatorów zorganizowanych w sieci może wytworzyć wartość, w rzeczywistości model ten otwiera proces produkcji danego przedsiębiorstwa na innowacyjność, redukując koszty i przyspieszając tempo owej produkcji, bez konieczności przeorganizowania swoich struktur i odnoszenia się do kwestii praw autorskich. Tymczasem w ekonomii P2Pp wartość produkowana jest w wyniku dobrowolnej kooperacji producentów, którzy mają pełen dostęp do dystrybuowanego w sieci kapitału, tworzą go bez tradycyjnych hierarchicznych struktur organizacyjnych i zasad finansowego wynagrodzenia, na zasadzie dóbr wspólnych i wspólnotowej formy własności ${ }^{28}$. Omawiany wyżej Openwear jest z założenia częścią tej tendencji, a programowe tworzenie kolektywnych kolekcji odróżnia go od innych projektów opartych na tworzeniu ubrań dzięki sieciom społecznym.

${ }^{24}$ Y. Benkler, The wealth of networks..., s. 277.

${ }^{25}$ M. Bauwens, The Political Economy...

${ }^{26}$ J. Howe, The Rise of Crowdsourcing, 2006, http://goo.gl/8QCtlQ [12.06.2014].

27 B. Niessen, Open Source, P2P, social innovation and clothing, w: B. Niessen i in., OpenWear. Sustainability..., ss. 51-54.

${ }^{28}$ M. Bauwens, The Political Economy...; więcej na temat różnic między P2P i crowdsourcingiem na stronie P2P Foundation, http://goo.gl/oNiUi3 [29.06.2014]. 


\section{Threadless - skuteczny crowdsourcing w modzie}

Powstała w 2000 r. chicagowska firma i platforma internetowa Threadless jest najbardziej znanym przykładem crowdsourcingu i komercyjnym zastosowaniem idei otwartości w modzie. Threadless wystartował jako konkurs na projekt t-shirtu, zorganizowany przez Jake’a Nickella i Jacoba DeHarta na forum dreemless.org - platformie, na której użytkownicy eksperymentowali z technologiami cyfrowymi, kodami i sztuką. Krótko potem założyli oni własną stronę, na której zaczęli organizować konkursy na projekty (głównie odzieżowe). Ich uczestnicy mogą pozyskać wzory i instrukcje tworzenia, które są dostępne na stronie, zamieszczać propozycje i głosować na nie według systemu głosowania w skali 0-5 w ciągu tygodnia, a zwycięskie projekty są nagradzane (2 tys. dolarów w gotówce i dodatkowo 500 dolarów do wykorzystania w ramach prezentów i bonów Threadless ${ }^{29}$ ), a następnie produkowane przez firmę i sprzedawane online. Przedmiotem projektu jest druk na ubraniu, nie zaś samo ubranie.

W pierwszych latach działalności firma produkowała koszulki co kilka miesięcy, dziś jest biznesem rozbudowanym wokół społecznej platformy zrzeszającej ponad 2,4 milionów użytkowników, mającym 323545 zgłoszonych projektów, 5953 wykonanych projektów i 80 pracowników ${ }^{30}$.

Threadless stanowi komercyjny przykład kultury prosumentów i „,innowacyjności użytkowników”31, gdyż „zamazuje granicę między producentem a konsumentem - konsumenci ostatecznie pełnią krytyczną rolę we wszystkich jej działaniach: generacji pomysłów, marketingu, przewidywaniu sprzedaży”32. Kojarzona jest też z pozytywnymi określeniami, takimi jak: partycypacja, bycie częścią społeczności, działanie poza utartymi schematami (obaj założyciele porzucili szkoły), świeżość oraz sukces ekonomiczny i zdolność rozwiązywania problemów. W odniesieniu do tych ostatnich głównym celem firmy jest pozyskiwanie atrakcyjnych i innowacyjnych projektów przeznaczonych do drukowania na odzieży, a następnie sprzedawania jej dla zysku. Rozwiązaniem proponowanym przez omawiany model crowsourcingu jest redukcja ryzyka inwestycji, kosztów projektowania i marketingu poprzez generowanie pomysłów przez społeczność internautów,

${ }^{29}$ D.C. Brabham, Moving the Crowd at Threadless, „Information, Communication \& Society" 13(8)/2010, s. 1124.

30 Dane na dzień 7.07.2014 r.

${ }^{31}$ E. von Hippel, Democratizing Innovation, Cambridge, Mass. - London 2006.

${ }^{32}$ M. Chavkin, The Customer is the Company, http://goo.gl/RhhZg6 [26.06.2014]. 
a następnie sprzedawania produktów owej społeczności lub na zamówienie klientów spoza niej. Retoryka firmy odwołuje się do idei crowsourcingu, w rzeczywistości jednak mamy tu do czynienia z modelem biznesowym, w którym konsumenci pracują dla producenta - pomysły generowane są przez wspólnotę użytkowników, a zwycięzcy nagradzani materialnie, zyski ze sprzedaży produktów czerpią jednak wyłącznie założyciele firmy.

\section{Otwarte szablony}

Rozwój Internetu i społeczeństwa sieciowego przyniósł możliwości rozwoju technik projektowania wspomaganych komputerowo CAD (Computer-Aided Design). PDS (Pattern Design Systems) stały się z czasem nieocenionymi narzędziami do tworzenia szablonów i wzorów projektowych, wykorzystywanymi w najbardziej powtarzalnych procedurach związanych z projektowaniem wykrojów. Ich niezaprzeczalnymi zaletami są szybkość, dokładność i zdolność szybkiego i łatwego w obsłudze przetwarzania i przekształcania ogromnej ilości danych. Na rynku obecnych jest wiele rozbudowanych i dostosowanych do systemów operacyjnych programów tego typu (AccuMark, PAD System, Pattern Works, Wild Ginger czy TukaTech), wciąż jednak są to stosunkowo drogie technologie, dlatego stosują je głównie duże firmy i instytucje edukacyjne.

Wielu projektantów zaczyna jednak eksperymentować z technologiami sieciowymi w swych projektach. Jednym z pierwszych awangardowych projektantów stosujących oprogramowanie komputerowe w projektowaniu jest Issey Miyake. Najdojrzalszym jego projektem w tym względzie jest „samoprzekształcający się strój”, przygotowany pod koniec lat 90. we współpracy z inżynierem tekstylnym Dai Fujiwarą i funkcjonujący pod kryptonimem A-POC (akronim A-Piece-of-Cloth, czyli kawałek materiału, a jednocześnie odniesienie do pojęcia epoch, czyli epoka ${ }^{33}$ ). A-POC jest metodą produkcji opartą na analizie kształtu kimona, używającą technologii cyfrowej i tradycyjnych maszyn dziewiarskich do tworzenia w jednym procesie uniwersalnego ubrania z jednego kawałka materiału. Z kolei Iris van Herpen, Catherine Wales i Francis Bitonti są prekursorami niszowego trendu projektowania i drukowania 3D, który zaczyna powoli opanowywać przemysł odzieżowy. Zwłaszcza van Herpen, futurystyczna projektantka haute couture, znana jest z łączenia tradycyjnego rzemiosła z technologiami cyfrowymi i innowacyjnymi odkryciami naukowymi.

${ }^{33}$ L. Benaïm, Issey Miyake, Paris 2007. 
Przedstawione przykłady, choć wykorzystują technologie cyfrowe do projektowania mody, nie są tworzone przy użyciu sieci społecznych ani w takich sieciach dystrybuowane. W XXI wieku pojawiło się jednak kilka projektów opartych na technologii cyfrowej, logice sieci oraz filozofii DIY i dzielenia się szablonami. Sama idea nie jest jednak nowa - w USA od XIX wieku dostępne były takie publikacje, jak: „Butterick”, „McCall’s”, „Vogue Patterns” czy „Simplicity”, funkcjonujące jako katalogi szablonów najnowszej mody światowej, z których można było zamówić wybrane wykroje papierowe. Każdy wzór zapakowany był w kopertę z ilustracją ubrania na okładce i instrukcją jego wykonania wewnątrz. W 1950 r. pojawił się natomiast niemiecki magazyn „Burda Modern”, który zyskał ogromną popularność, gdy w 1952 r. zaczął zamieszczać papierowe wykroje prezentowanych strojów. Był też pierwszym czasopismem zachodnim wydawanym w krajach komunistycznych, a obecnie ukazuje się jako „Burda Style” w 89 krajach i 16 wersjach językowych. Na fali trendu retro i nostalgii za dawnymi czasami wiele dawnych papierowych szablonów i wykrojów dostępnych jest w sprzedaży w internetowych sklepach tematycznych czy sieciach typu eBay i Allegro.

Do cyfrowych projektów, które w większym stopniu angażują użytkowników i czynią ich działalność widzialną i dostępną społecznie, należy pionierska platforma cyfrowa showstudio.com (opracowana w 2000 r. przez brytyjskiego fotografa mody Nicka Knighta jako przestrzeń prezentowania mody w epoce cyfrowej). W 2002 r. rozpoczęła projekt Design Download, którego głównym celem jest „objaśnienie procesu [produkcji] mody, poprzez oferowanie wzoru ubrania cenionego projektanta do pobrania za darmo przez Internet” ${ }^{34}$. Użytkownicy zachęcani są do darmowego pobrania wykroju znanego projektanta mody, wykonania ubrania na jego podstawie i udostępnienia zdjęcia ukończonej pracy. Zwycięska praca jest następnie zamieszczana na stronie projektu. Użytkownicy mogli się np. zapoznać z ostrymi cięciami Alexandra McQueena w kurtce inspirowanej japońskim kimonem, niedokończonym ubraniem Martina Margieli czy nieoczywistym strojem Yohji Yamamoto, które można było dowolnie dookreślić. Design Download nie jest oczywiście jedynym przykładem, tego, że znani projektanci udostępniają swe projekty szerszej publiczności (np. „Vogue Patterns” drukowało projekty Calvina Kleina, Ralpha Laurena, Alberta Fabianiego czy Diane von Furstenberg; „Burda Style” dwa projekty Karla Lagerfelda, a „Die Zeit” projekt Hediego Slimene’a). Cyfrowy projekt Showstudio wy-

\footnotetext{
${ }^{34}$ Design Download: Yohji Yamamoto, http://goo.gl/jNDHD0 [30.06.2014].
} 
różnia jednak udostępnianie wykrojów całkowicie za darmo oraz możliwość zaangażowania się użytkowników w proces produkcji ubrania i konkurs na najlepszą adaptację projektu.

Darmowe szablony, wykroje i instrukcje są również elementem założonego w 2012 r. internetowego serwisu makersrow.com, oferującego pomoc w procesie produkcji odzieży małym i średnim przedsiębiorcom w USA. Nie chodzi tutaj o dostęp do wykrojów projektantów z najwyższej modowej półki, ale o uczynienie procesu produkcji odzieży prostym do zrozumienia i łatwo dostępnym, a także wzmocnienie lokalnej twórczości.

Na podobnych założeniach opiera się projekt Open Garments (Otwarta odzież), przygotowany przez konsorcjum firm europejskich i finansowany przez Komisję Europejską, który ma ambicje stać się platformą umożliwiającą odbiorcom występowanie w roli projektantów, producentów i sprzedawców ubrań dostosowanych do indywidualnych potrzeb i gustów. Ważnym celem projektu jest tworzenie dostępnej członkom sieci bazy cyfrowych technologii projektowania i produkowania odzieży w ramach koncepcji „otwartej innowacji” i „otwartej produkcji” oraz włączanie ich w nowy model biznesowy dostawcy usług produkcyjnych, który koordynuje, wspiera i częściowo zarządza społecznością użytkowników.

Na zakończenie warto wspomnieć o komercyjnym projekcie BurdaStyle. com, opartym na nieco innym koncepcie niż papierowy magazyn „Burda Style”. Założona w 2007 r. internetowa platforma oferuje odpłatnie szablony przygotowane przez zespół projektantów „Burdy”, jednak część szablonów, wykrojów i instrukcji udostępnia nieodpłatnie, a ponadto zachęca użytkowników do zamieszczania własnych. Służy temu zwłaszcza sekcja „How-to”, forum oraz prowadzony na stronie blog. Jak twierdzą pomysłodawcy, BurdaStyle.com jest platformą, którą „urzekła filozofia otwartych kodów źródłowych: dzielenie własności intelektualnej i pozwalanie naszym członkom na remiksowanie, odtwarzanie, pobieranie próbek i tworzenie nowych wzorów. [...] Wierzymy, że usunięcie praw autorskich z naszych projektów będzie inspirować kreatywność i zaiskrzy wieloma nowymi projektami - i to jest wspaniałe!”35. BurdaStyle.com jest ciekawym eksperymentem wprowadzania nowych rozwiązań, w wielu aspektach funkcjonuje jednak w tradycyjnym modelu biznesowym - nie wszystkie wykroje i szablony są udostępniane za darmo ani opracowywane kolektywnie, strona utrzymuje się ze sprzedaży wykrojów dostępnych w sklepie online oraz wirtualnej prze-

${ }^{35}$ What Is Open Source Sewing?, http://goo.gl/rwqNAQ [29.06.2014]. 
strzeni reklamowej, a odpłatne projekty opatrzone hasłem „zaprojektowane przez burdastylemagazine” podlegają prawom autorskim.

Podobnie wiele blogów modowych, cyfrowych magazynów o modzie i mediów społecznościowych nie zawsze koncentruje się na dzieleniu się, współtworzeniu gotowych wzorów, wykrojów czy omawianiu metod tworzenia i produkcji ubrań i akcesoriów. Z tego względu praktyki te nie zostały tutaj omówione.

\section{Nowy paradygmat?}

Podobnie jak Charles Leadbeater wskazujący różne poziomy filozofii „,we-think”36, możemy mówić o skali otwartości w systemie mody - pełnej otwartości, średniej, niskiej aż po zamkniętość. Modę otwartych źródeł cechuje rzecz jasna najwyższa otwartość, prezentowana na każdym poziomie: od otwartych i wspólnotowych metod projektowania, przez otwartą produkcję, dystrybucję, konsumpcję i czerpanie profitów materialnych i społecznych. Openwear i praktyki haktywistów najpełniej realizują ten model. Proponowane przez nie pojęcie otwartości nie sprowadza się tylko do dopuszczania różnych klas społecznych do konsumpcji mody (tradycyjna definicja systemu mody) czy ukazywania transparentności procesu produkcji odzieży i cyklu życia mody (definicja stosowana z jednej strony przez przedstawicieli modowego dekonstruktywizmu, z drugiej - przez ruch etyczności i zrównoważonego rozwoju w modzie). Promuje dodatkowo samowystarczalność, DIY, kolektywną kreatywność i udział w modzie poprzez sieci społeczne. W ten sposób przekodowuje podstawowe reguły i strukturę systemu mody - tradycyjny podział na producentów i konsumentów, scenę i kulisy oraz centralną rolę projektanta/marki skupiającego na sobie całą uwagę.

Każda produkcja kulturowa, również moda, jest postrzegana przez zwolenników analizowanego fenomenu jako proces kolektywny, programowo niedokończony i otwarty na modyfikacje i przekształcenia, a nie na rezultat końcowy pracy relatywnie wyizolowanej jednostki. Etyka hakerska i kultura DIY odwołuje się do pojęcia remiksu, czyli manipulacji i przekształcania dzieła pierwotnego, w celu tworzenia nowego znaczenia i przekazu. Idee te idą w parze z logiką mody, w której - wbrew powszechnemu przekonaniu i mitowi genialnego projektanta - nie ma ochrony własności intelektual-

${ }^{36}$ Ch. Leadbeater, We Think..., s. 84. 
nej ${ }^{37}$, działa „paradoks piractwa”38 (kopiowanie wspiera innowacyjność), a „oryginał” trudny jest do oddzielenia od „kopii”. Moda jest nieustającym dialogiem, w którym każdy ma coś do (do)powiedzenia. Dla przedstawicieli otwartych źródeł nie oznacza to jednak rezygnacji z autorstwa. Im bardziej bowiem ludzie będą zaangażowani w proces twórczy, tym jaśniejsze będzie, kto zanicjował proces i kto w nim za co odpowiada ${ }^{39}$.

Moda otwartych kodów źródłowych jest także zamachem na tradycyjne myślenie o modzie jako działalności prowadzonej wyłącznie dla zysku i kierującej się logiką ekonomicznej opłacalności. Analizowane projekty akcentują wagę wartości społecznych i korzyści nieekonomicznych, takich jak: partycypacja, upodmiotowienie jednostek, poszerzanie zakresu wiedzy i modowych kompetencji oraz traktowanie transformacyjnych właściwości mody jako dobra wspólnego.

Biorąc pod uwagę skalę skutecznych interwencji w system, zaproponowanych przez badaczkę złożoności systemów, Donellę Meadows ${ }^{40}$, można uznać, że praktyki ruchu otwartych źródeł w modzie programowo odnoszą się do: przepływu informacji (sieci cyfrowe, przejrzystość reguł i działań, dostęp), reguł systemu (relacje między podmiotami, własność intelektualna), siły samoorganizacji (wiedza, narzędzia, umiejętności, upodmiotowienie), celów systemu (decentralizacja, wspieranie lokalności), paradygmatu systemu (totalna otwartość). W koncepcji Meadows punkty te traktowane są jako obszary, za pomocą zmiany których najefektywniej można dokonać przekształcenia danego systemu.

Omówione w artykule przykłady stanowią próbę ustanawiania nowego paradygmatu, przekodowania dotychczasowych celów, struktury, reguł, idei i kultury systemu mody. Pozytywne skojarzenia z takimi kwestiami, jak: bycie razem, równość, kolektywna produkcja i demokratyczne podejmowanie decyzji, buduje przekonanie, że moda otwartych źródeł to oddolnie

37 Badania Davida Bolliera i Laurie Racine pokazują, że ochrona własności intelektualnej w modzie może być stosowana jedynie do projektów tkanin, specyficznych elementów ornamentowych, tkanin i tworzyw sztucznych oraz logo marki. Cytowanie, próbkowanie, miksowanie i inne formy brikolażu są nie tylko dozwolone, ale stanowią sedno procesu produkcyjnego. D. Bollier, L. Racine, Ready to Share: Fashion and the Ownership of Creativity, 2006, http://tinyurl.com/zx7fyws [29.06.2014].

${ }^{38}$ K. Raustiala, Ch.J. Sprigman, The Piracy Paradox Revisited, „Stanford Law Review” 61(5)/2009.

39 Z. Romano, Activating knowledge and empowering clothing communities with open source fashion, http://goo.gl/2nEd1b [30.06.2014].

40 D. Meadows, Leverage Points: Places to Intervene in a System, 1999, http://goo. gl/iXxfUd [30.06.2014]. 
inicjowane przedsięwzięcia służące interesom wspólnotowym i lokalnym, że to doświadczenie społeczne, a nie komercyjne, i obietnica zmiany świata mody w prawdziwie demokratyczny system, a pasywnych konsumentów w (współ)twórców mody.

Postulowany nowy paradygmat nie jest jednak wolny od ograniczeń i trudnych kwestii, podobnych do problemów filozofii otwartych źródeł w ogóle. Pierwsza z nich sprowadza się do problemu eksploatacji (ryzyko przejęcia własności intelektualnej nad otwartym projektem przez kogoś, kto nie brał udziału w jego wytwarzaniu; ryzyko wykorzystania wielu pomocnych rąk do produkcji projektów i zawartości wykorzystywanych komercyjnie; nieopłacana praca na rzecz firmy; odgórne zarządzanie przestrzenią sieci społecznej przez firmę). Druga to problem zysków w sytuacji niskiej opłacalności ekonomicznej działań realizowanych w modelu otwartych źródeł. Trzecia to problem braku motywacji i chęci partycypacji w takim systemie mody ze strony jednostek (niechęć do wzięcia odpowiedzialności, wydatkowania czasu i środków na produkcję odzieży, uczenia się nowego języka, umiejętności i kompetencji modowych). Czwarta to brak możliwości udziału w nowym systemie mody (wykluczenie cyfrowe, bariera językowa - większość dostępnych źródeł jest w języku angielskim, brak dostępu do materiałów i surowców). I ostatnia to problem technologicznej i logistycznej organizacji sieci użytkowników o różnych zdolnościach w zakresie projektowania, krawiectwa, szycia itp. oraz problem z przełożeniem bogactwa cyfrowych informacji na materialną praktykę.

\section{Literatura}

Arvidsson A., The ethical economy of customer coproduction, „Journal of Macromarketing” 28(4)/2008.

Bauwens M., The Political Economy of Peer Production, 2006, http://goo.gl/lxjkLK [20.05. 2014].

Beer D., Burrows R., Sociology and, of and in Web 2.0: Some Initial Considerations, 2007, http://goo.gl/btDwNR [13.06.2014].

Benaïm L, Issey Miyake, Paris 2007.

Benkler Y., The wealth of networks: How social production transforms markets and freedom, New Haven 2006.

Bollier D., Racine L., Ready to Share: Fashion and the Ownership of Creativity, 2006, http:// tinyurl.com/zx7fyws [29.06.2014].

Brabham D.C., Moving the Crowd at Threadless, „Information, Communication \& Society” 13(8)/2010.

Busch O. von, Engaged Design and the Practice of Fashion Hacking: Examples of Giana Gonzalez and Dale Sko, „Fashion Practice” 1(2)/2009. 
Busch O. von, Fashion-able. Hacktivism and engaged fashion design, Göteborg 2008.

Busch O. von, Hacking Design, http://goo.gl/FQXFao [29.06.2014].

Busch O. von, Self_passage >. Collected methods, http://goo.gl/pSzDPZ [15.05.2014].

Chavkin M., The Customer is the Company, http://goo.gl/RhhZg6 [26.06.2014].

Design Download: Yohji Yamamoto, http://goo.gl/jNDHD0 [30.06.2014].

Hatalska N., Trend Book 2014, http://goo.gl/UNcNa2 [27.05.2014].

Hippel E. von, Democratizing Innovation, Cambridge, Mass. - London 2006.

Howe J., The Rise of Crowdsourcing, 2006, http://goo.gl/8QCtlQ [12.06.2014].

Leadbeater Ch., We Think. Mass innovation not mass production, London 2009.

Meadows D., Leverage Points: Places to Intervene in a System, 1999, http://goo.gl/iXxfUd [30.06.2014].

Niessen B. i in., OpenWear. Sustainability, openness and P2P production in the world of fashion, 2010, http://tinyurl.com/kyxppvs [29.06.2014].

Openwear: http://goo.gl/2C3Uzv [2.06.2014].

P2P Foundation, http://goo.gl/oNiUi3 [29.06.2014].

Raustiala K., Sprigman Ch.J., The Piracy Paradox Revisited, „Stanford Law Review” 61(5)/ 2009.

Raymond E., How To Become A Hacker, 2001, http://goo.gl/1PLWiP [15.06.2014].

Raymond E., The Cathedral and The Bazaar, Musings on Linux and Open Source by an Accidental Revolutionary, Cambridge, Mass. 2001.

Romano Z., Activating knowledge and empowering clothing communities with open source fashion, http://goo.gl/2nEd1b [30.06.2014].

Sanders L., Stappers P., Co-creation and the new landscapes of design, „CoDesign” 4(1)/ 2008.

Sanders L., Westerlund B., Experiencing, Exploring and Experimenting in and with Co-Design Spaces, 2011, http://goo.gl/tXmVuY [30.05.2014].

Scaturro S., Open Source Fashion: For the Masses, by the Masses, http://goo.gl/LqKFeI, [15.05.2014].

The Whole Earth Catalog, http://goo.gl/6pizmW [10.06.2014].

Wark McKenzie, A Hackers Manifesto, Cambridge 2004.

What Is Open Source Sewing?, http://goo.gl/rwqNAQ [29.06.2014]. 